\title{
Inhibition of population growth in the copepods Acartia clausi and Calanus helgolandicus during diatom blooms
}

\author{
A. Miralto ${ }^{1}$, L. Guglielmo ${ }^{2}$, G. Zagami ${ }^{2}$, I. Buttino ${ }^{1}$, A. Granata ${ }^{2}$, A. Ianora ${ }^{1, *}$ \\ ${ }^{1}$ Ecophysiology Laboratory, Stazione Zoologica A. Dohrn, Villa Comunale, 80121 Naples, Italy \\ ${ }^{2}$ Department of Animal Biology and Marine Ecology, University of Messina, Salita Sperone 31, 98166 Messina-S. Agata, Italy
}

\begin{abstract}
Field evidence is presented showing that hatching success in the copepods Acartia clausi and Calanus helgolandicus was greatly modified during 2 major late-winter diatom blooms in the North Adriatic (Mediterranean) Sea in 1997 and 1998 compared to post-bloom conditions in early summer of 1997. In February of both years, diatoms represented $>90 \%$ of the microplankton at all depths of inshore stations, and from 40 to $95 \%$ at different depths of offshore stations. The diatom blooms differed between the $2 \mathrm{yr}$ in that Skeletonema costatum (66.3\%) and Pseudo-nitzschia delicatissima $(23.2 \%)$ dominated in 1997, whereas the following February the bloom was almost entirely composed of $P$. delicatissima (80.6\%). In June 1997, diatoms were much less abundant, even though they still comprised about $50 \%$ of the algal population at some of the more coastal stations; the diatom species composition in this period had shifted to a dominance of Chaetoceros decipiens and Dactlyliosolen fragilissimus. The population structure and vertical distribution of the copepods A. clausi and C. helgolandicus were examined to determine the effects of these diatom blooms on population recruitment rates. A. clausi was the most abundant copepod sampled in June, constituting $47.7 \%$ of total copepod numbers, whereas low abundances were recorded in February 1997 (1.6\%) and 1998 (1.8\%). C. helgolandicus numbers were also low in winter 1998 (0.82\% of total copepod numbers). Egg production rates (EPR) for $A$. clausi were highest during the blooms, with values of 10.6 and 18.4 eggs female $\mathrm{e}^{-1} \mathrm{~d}^{-1}$ in 1997 and 1998 respectively, compared to 6.2 eggs female $\mathrm{e}^{-1} \mathrm{~d}^{-1}$ in June 1997 . However the most dramatic differences between bloom and post-bloom conditions were in terms of egg hatching viability, with mean values of 15.4 and $16.1 \%$ in February 1997 and 1998 respectively, as opposed to $89.1 \%$ in June. Fecal pellet numbers for females were highest in winter, indicating active feeding on diatoms. Total egg production rate (TEP, the product of EPR and total number of females $\mathrm{m}^{-3}$ ) was much greater in June (863 eggs m${ }^{-3} \mathrm{~d}^{-1}$ ) than in February 1997 (17.6 eggs $\left.\mathrm{m}^{-3} \mathrm{~d}^{-1}\right)$ and $1998\left(140\right.$ eggs m$\left.^{-3} \mathrm{~d}^{-1}\right)$ due to the higher number of females in early summer. In turn, naupliar recruitment rates (TNR) were extremely high in June (790.2 nauplii $\mathrm{m}^{-3} \mathrm{~d}^{-1}$ ) as opposed to February 1997 (2.8 nauplii $\mathrm{m}^{-3} \mathrm{~d}^{-1}$ ) and February 1998 (15.6 nauplii $\mathrm{m}^{-3} \mathrm{~d}^{-1}$ ). EPR for C. helgolandicus in February 1998 was low (9.7), with only $6.5 \%$ hatching viability. Values for TEP $\left(54\right.$ eggs $\left.\mathrm{m}^{-3} \mathrm{~d}^{-1}\right)$ and TNR $\left(4.7\right.$ nauplii $\left.\mathrm{m}^{-3} \mathrm{~d}^{-1}\right)$ were lower than for A. clausi. We conclude that the main factor responsible for reduced population recruitment rates of both species in winter was low hatching viability and that the bulk of annual recruitment in the North Adriatic Sea occurred in post-bloom conditions, since the mixed protistan community that succeeded the bloom was probably a better food source for copepod embryogenesis. The results are discussed in relation to laboratory findings on the toxic effects of diatoms on copepod reproduction.
\end{abstract}

KEY WORDS: Diatoms · Copepods · Distribution $\cdot$ Egg production $\cdot$ Hatching success

Resale or republication not permitted without written consent of the publisher

\section{INTRODUCTION}

Diatoms are unicellular algae at the base of the marine food chain that have a pivotal role in the trans- fer of energy to top consumers and important fisheries. However, there is accumulating evidence to challenge the view that diatoms are good and harmless food items for the reproduction and development of zoo- 
plankton crustaceans such as copepods. Although diatoms are a good source of food for copepod fecundity and survival, laboratory studies have demonstrated that several diatom species contain insidious compounds that compromise hatching viability when ingested (see Ianora et al. 2003 for a recent review). The secondary metabolites responsible for these effects have been identified as 2-trans-4-cis-7-cis-decatrienal, 2-trans-4-trans-7-cis-decatrienal and 2-trans-4-transdecadienal unsaturated aldehydes (Miralto et al. 1999), hereafter referred to as decatrienals 1 and 2, respectively and decadienal. Decatrienals 1 and 2 had already been identified in the freshwater diatom Melosira varians (Wendel \& Jüttner 1996), but the biological function of these molecules was unknown at the time. Miralto et al. (1999) showed that all 3 unsaturated aldehydes had anti-cell growth activity in that they blocked the development of copepod embryos and cleavage of sea urchin embryos, and inhibited the proliferation of human carcinoma cells in a dose-dependent manner. These authors suggested that diatom aldehydes are the probable agents of reproductive failure in copepods when diatoms are the major food source.

Pohnert (2000) showed that when diatoms become damaged due to grazing there is a rapid onset of aldehyde production seconds after cell disruption, similar to the wound reaction in higher plants (Rosahl 1996). Pohnert (2000) also showed that this mechanism of chemical defence is initiated by phospholipases, with a drastic increase in the amount of free polyunsaturated eicosanoids in the first few minutes after wounding. Using fluorescent probes, Pohnert (2002) has characterised the main enzyme activity responsible for initiation of the aldehyde-generating lipase-lipoxygenasehydroperoxide lyase cascade as phospholipase A2. In contrast to higher plants, which use lipases acting on galactolipids to release C18 fatty acids for production of leaf volatile aldehydes, diatoms rely on phospholipids and the transformation of C20 fatty acids to form decatrienals 1 and 2 and decadienal-unsaturated aldehydes as an activated defence.

Until now, most of the evidence of the inhibitory effects of diatoms on egg hatching success derives from laboratory feeding experiments showing that some diatoms can reduce egg viability by up to $100 \%$ (Poulet et al. 1994, 1995b, Ianora et al. 1995, 1996, 1999, Uye 1996, Starr et al. 1999, Lacoste et al. 2001, Ceballos \& Ianora in press). Mixed diets dilute but do not delete this negative effect on viability (Ban et al. 2000, Kang \& Poulet 2000, Lacoste et al. 2001, Turner et al. 2001). For example, Turner et al. (2001) showed that reduced egg viability in the copepod Temora stylifera occurred with different combinations of a diet mixture of the diatom Thalassiosira rotula and the dinoflagellate Prorocentrum minimum. Hatching was reduced by approximately half, and took about twice as long to occur, suggesting that diatom-derived aldehydes are, in fact, the causative agents for reduced hatching.

Turner et al. (2001) also measured daily ingestion rates of the copepod Temora stylifera for 10 consecutive days on a mixture of Thalassiosira rotula and Prorocentrum minimum, and showed that ingestion rates in terms of carbon were similar with both algae, even though Temora stylifera was offered more P. minimum in terms of carbon. This apparent preference for the diatom cells indicated that the reactive aldehydes produced upon breakage of diatom cells did not deter feeding. The Thalassiosira rotula strain from the Gulf of Naples used in the study by Turner et al. (2001) was shown to produce reactive aldehydes that block copepod egg hatching viability (Miralto et al. 1999, d'Ippolito et al. 2002a, Pohnert et al. 2002) compared to another T. rotula strain from the California coast (TR2) which does not produce these compounds (Pohnert et al. 2002).

At this point, it seems important to clarify whether certain diatoms also induce deleterious effects on copepod reproduction in situ. Very few studies of this kind exist to date. Ianora \& Poulet (1993) observed that low hatching success in Temora stylifera in the Bay of Naples occurred in late winter and early spring, when the phytoplankton populations were dominated by diatoms. Laabir et al. (1995) found highly varying egg viability in Calanus helgolandicus during a year-long study in the English Channel off Roscoff, France, where there was a time lag between the occurrence of maximum proportions of diatoms in the fecal pellets and reduced hatching success. During a 10 mo field study in Ría de Vigo, Spain, Guisande et al. (2000) found that hatching success in Euterpina acutifrons was strongly correlated with food quality, and that higher hatching success occurred when the similarity between the amino acid composition of eggs and females and the amino acid composition of females and seston was higher. However, reduced hatching success was observed when diatoms constituted more than $70 \%$ of the phytoplankton, in which case these relationships were no longer valid. Mesocosm experiments off the Norwegian coast indicated a drop of $>95 \%$ in the reproductive success of $C$. helgolandicus during a diatom bloom even though feeding rates were high and alternative prey items were available (Nejstgaard et al. 2001). A high incidence (20 to $40 \%$ ) of abnormal Pseudocalanus newmani nauplii was reported by Ban et al. (2000) during a diatom bloom in the Sea of Japan. Although these authors could not obtain clear evidence of an in situ deleterious effect of diatoms on abnormal nauplii, they concluded that this effect must have been provoked by diatoms since deformities of copepod nauplii have not yet been observed for reasons other than feeding on diatoms. 
The first strong field evidence of inhibitory effects of diatoms was reported by Miralto et al. (1999), who found that hatching success in Acartia clausi was greatly modified during 2 major late-winter diatom blooms in the North Adriatic (Mediterranean) Sea. These authors reported that egg viability in A. clausi was only 12 and $24 \%$ in February 1997 and February 1998 , respectively, of the total number of eggs produced compared with $90 \%$ during post-bloom conditions in June 1997. Herein, we examine in detail the distribution of both A. clausi and Calanus helgolandicus in the North Adriatic Sea during the same diatom bloom and post-bloom events, and calculate potential recruitment and population growth rates of these species in these periods. The results are discussed in relation to laboratory findings on the toxic effects of diatoms on copepod reproduction.

\section{MATERIALS AND METHODS}

Study area. The northern Adriatic is the shallowest and most dynamic region of the Adriatic Sea. The coastal water mass circulation in this region is strongly influenced by freshwater outflow from the Po river which spreads in the surface layer, forming a plume that is separated from more saline Adriatic waters and giving rise to a frontal system (Grancini \& Cescon 1973). This system is established in the northern basin for most of the year (Franco 1983, Fonda Umani et al. 1992); the system clearly separates neritic, eutrophic waters from oligo-mesotrophic offshore waters, producing 2 independent and ecologically different envi- ronments (Franco 1984, Smodlaka 1986, Fonda Umani et al. 1994, Alberighi et al. 1997). These characteristics determine cyclic variations within the water column, causing a complete instability in winter as opposed to a clear stratification the rest of the year (Fonda Umani et al. 1992). Consequently, the retention and diffusion of diluted waters control biogeochemical fluxes throughout the water column and along the inshore and offshore sides of the frontal system.

Sampling strategy. Two oceanographic cruises were conducted during strong winter diatom blooms in the Northern Adriatic Sea in February 1997 and February 1998. A third cruise was conducted in June 1997 when post-diatom bloom conditions were established. Station locations along different inshore-offshore transects for the 3 cruises are shown in Fig. 1. The strategy was to sample 2 study areas with different salinity regimes, the first close to the Po Delta (northern area) and the second located between Rimini and Ancona (southern area). Each sampling area comprised 4 to 8 stations selected after a preliminary hydrobiological survey to identify the presence of frontal systems. The geographical position of the sampling transects varied among cruises according to the position of the frontal system.

Phytoplankton samples were collected using 101 Niskin bottles at 5 selected optical depths (Vadrucci et al. 2002), and 1 sample near the bottom. On board ship, samples were fixed with Lugol solution at a final concentration of $1 \%$. In the laboratory, phytoplankton samples were settled in Utermöhl chambers and then examined under the light microscope to determine different algal groups and species composition.
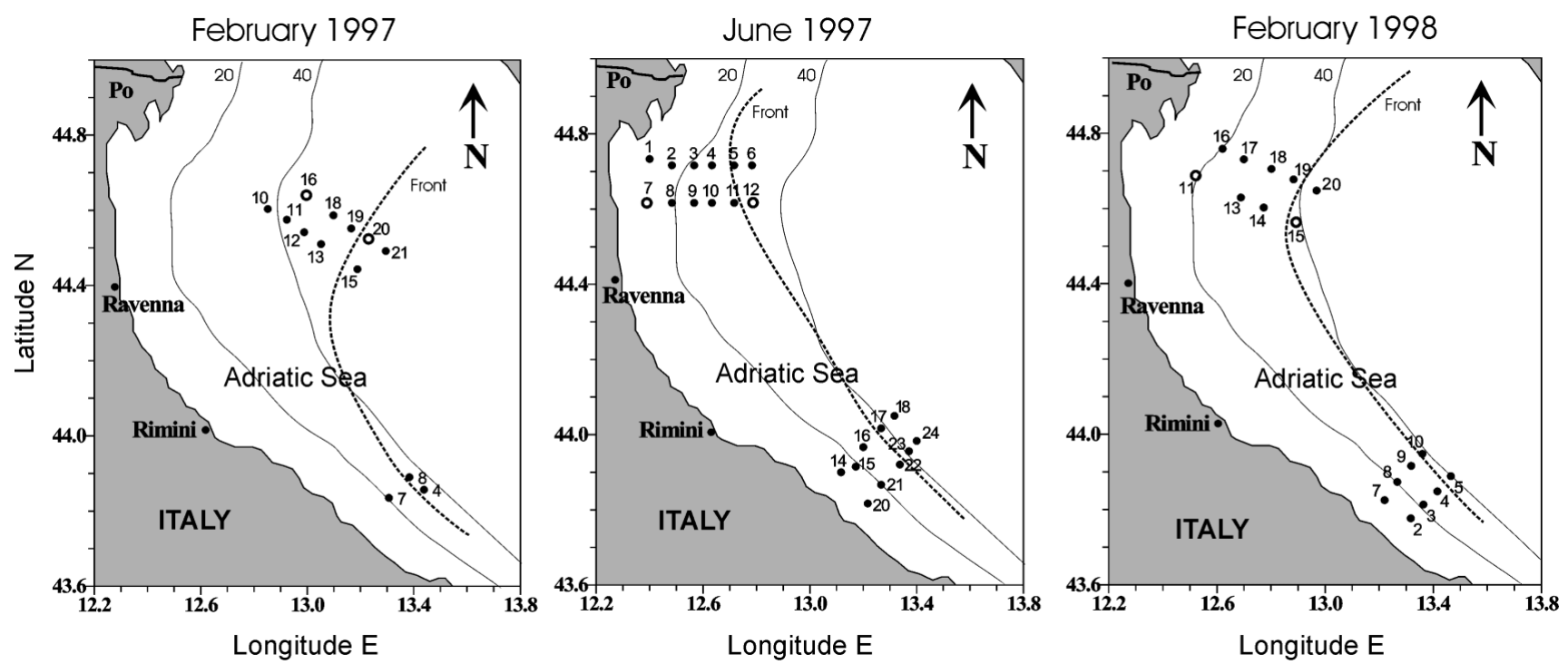

Fig. 1. Sampling sites in the North Adriatic (Mediterranean) Sea during 3 cruises in Febrary 1997 and 1998 , and June 1997. (O) selected inshore and offshore stations with respect to the frontal system in the morthern basin (see first paragraph of 'Materials and methods') 
Zooplankton samples were collected by an electronic multinet BIONESS, a multiple opening and closing net sampler with five $200 \mu \mathrm{m}$ mesh-size nets, each with a square mouth opening of $0.25 \mathrm{~m}^{2}$ (Sameoto et al. 1980). The BIONESS continuously measured temperature, salinity and depth during tows by means of a multiprobe KMS II (ME Meerestechnik). Fluorescence was measured continuously by a 'Dr Haardt Fluorometer' and flow through the nets was monitored using external and internal SM11 Doppler flowmeters. The BIONESS was towed at a speed of 1.5 to $2 \mathrm{~m} \mathrm{~s}^{-1}$ as it was slowly lowered along an oblique path to the desired depth. Fishing upward, the nets were opened and closed on command at 5 to $10 \mathrm{~m}$ intervals, depending on the bottom depth and according to different water masses. On board ship, samples were preserved with buffered formaldehyde $4 \%$ seawater solution for microscopic analysis.

To obtain information on in situ rates of egg production, egg-hatching viability and fecal pellet production for these copepod species, live zooplankton samples were collected using a $200 \mu \mathrm{m}$ Nansen net since this net is more manageable for the capture of live animals. The net was gently towed obliquely from $20 \mathrm{~m}$ to the surface, and on board ship about 20 female Acartia clausi from each station were separated and individually incubated in $50 \mathrm{ml}$ tissue-culture flasks using $50 \mu \mathrm{m}$ filtered seawater with a natural phytoplankton assemblage. In February 1998, an equal number of female Calanus helgolandicus were also separated and incubated individually in $50 \mathrm{ml}$ tissue culture flasks with natural phytoplankton.

Laboratory procedures. A qualitative-quantitative analysis of meso-zooplankton was carried out on subsamples from the BIONESS, ranging from 1/10 to $1 / 20$ of the original sample, depending on the richness of the sample. Specimens were sorted and divided per taxa. Adult copepods and their development stages were identified to species level, and the number of adult female and male Acartia clausi and Calanus helgolandicus were quantified. The number of younger Copepodite Stages CI to V of these 2 species was also determined, but for $A$. clausi we report only the number of Stages CII to CV, since Stage CI may not have been captured efficiently due to the large mesh size of the net. All abundance values are expressed as individuals (ind.) $100 \mathrm{~m}^{-3}$.

Flasks containing live females for egg production measurements were kept at $12^{\circ} \mathrm{C}$ (February) or $20^{\circ} \mathrm{C}$ (June). After $24 \mathrm{~h}$, the contents were poured into a crystallizing dish, the females were removed, and the number of eggs and fecal pellets were counted with an inverted miscroscope. The contents were then repoured into the original flask and kept at $20^{\circ} \mathrm{C}$ for $48 \mathrm{~h}$ to allow for hatching of eggs, considering that egg development times for both Acartia clausi and Calanus helgolandicus at $20^{\circ} \mathrm{C}$ are ca. $24 \mathrm{~h}$ (Ianora 1998). After fixation with $4 \%$ formaldehyde, the number of hatched nauplii was determined under an inverted microscope.

Production and recruitment rates were calculated by the method of Poulet et al. (1995a). Egg production rates $\left(E P R=\right.$ eggs female $\left.{ }^{-1} \mathrm{~d}^{-1}\right)$ were determined for individual females. Total egg production rates $\mathrm{m}^{-3}$ $\left(\mathrm{TEP}=\mathrm{EPR} \times\right.$ number of females $\left.\mathrm{m}^{-3}\right)$ and total nauplii recruited $\mathrm{m}^{-3}\left(\mathrm{TNR}=\mathrm{EPR} \times\right.$ number of females $\mathrm{m}^{-3} \times$ $\%$ viable eggs) were then calculated for each station.

Initial results on the diatom bloom composition and egg production and hatching viability of Acartia clausi in the North Adriatic Sea were reported by Miralto et al. $(1999,2002)$. Herein, we examine the data for 52 stations in which measurements are available for both A. clausi and Calanus helgolandicus egg production/ hatching viability and adult female/male and copepodite population numbers in order to calculate potential copepod production and recruitment rates during diatom bloom and post-bloom conditions.

\section{RESULTS}

The 3 cruises in the North Adriatic Sea coincided with strong diatom (February 1997 and 1998) and postdiatom (June 1997) bloom events. Fig. 2 shows the vertical profiles for temperature, salinity and fluorescence at 2 representative stations for each cruise, 1 inshore of the front and 1 offshore of the front, hereafter referred to as inshore and offshore stations, respectively. In February of both years, the 2 inshore stations Stns 16 and 11 had maximal fluorescence values at $<5$ and $<10 \mathrm{~m}$, respectively, whereas at the 2 offshore stations (Stns 20 and 15) values were more evenly distributed throughout the water column. Fluorescence values were much higher at inshore than offshore stations, and much higher in 1997 than in 1998. Surface temperatures in February were low, 9 to $10^{\circ} \mathrm{C}$, and characterised by lower salinities due to freshwater runoff from the nearby River Po. In June, fluorescence values had risen to nearly twice those in February. Temperatures were much higher at the surface, with stratified conditions at both inshore (Stn 7) and offshore (Stn 12) stations, and salinities were again lower in surface waters due to freshwater runoff.

The late-winter bloom of both years was strongly dominated by diatoms representing $>90 \%$ of the phytoplankton population at all depths at inshore stations (Stns 16 and 11), and from 40 to $95 \%$ at different depths at the offshore stations (Stns 20 and 15: Fig. 3). The diatom blooms differed in the 2 yr of sampling in that Skeletonema costatum (66.3\%) and Pseudo-nitzschia delicatissima (23.2\%) dominated in 1997 (Cabrini et al. 


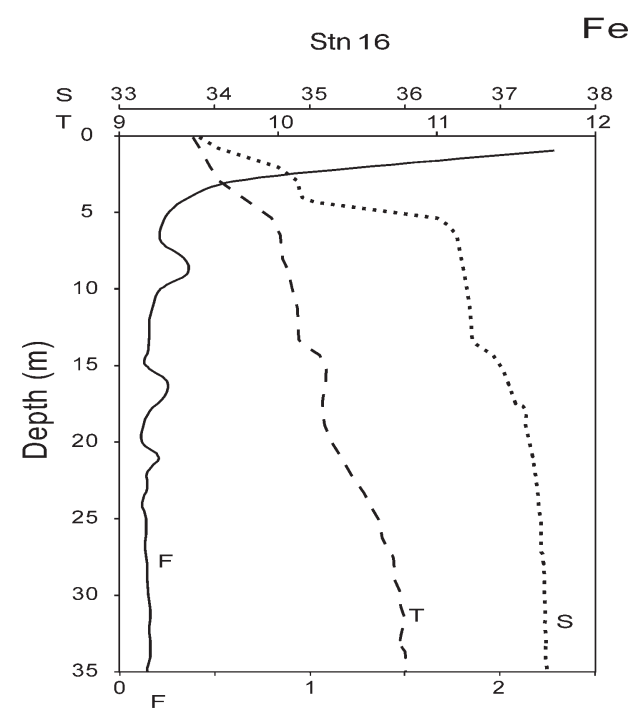

February 1997

$\operatorname{Stn} 20$
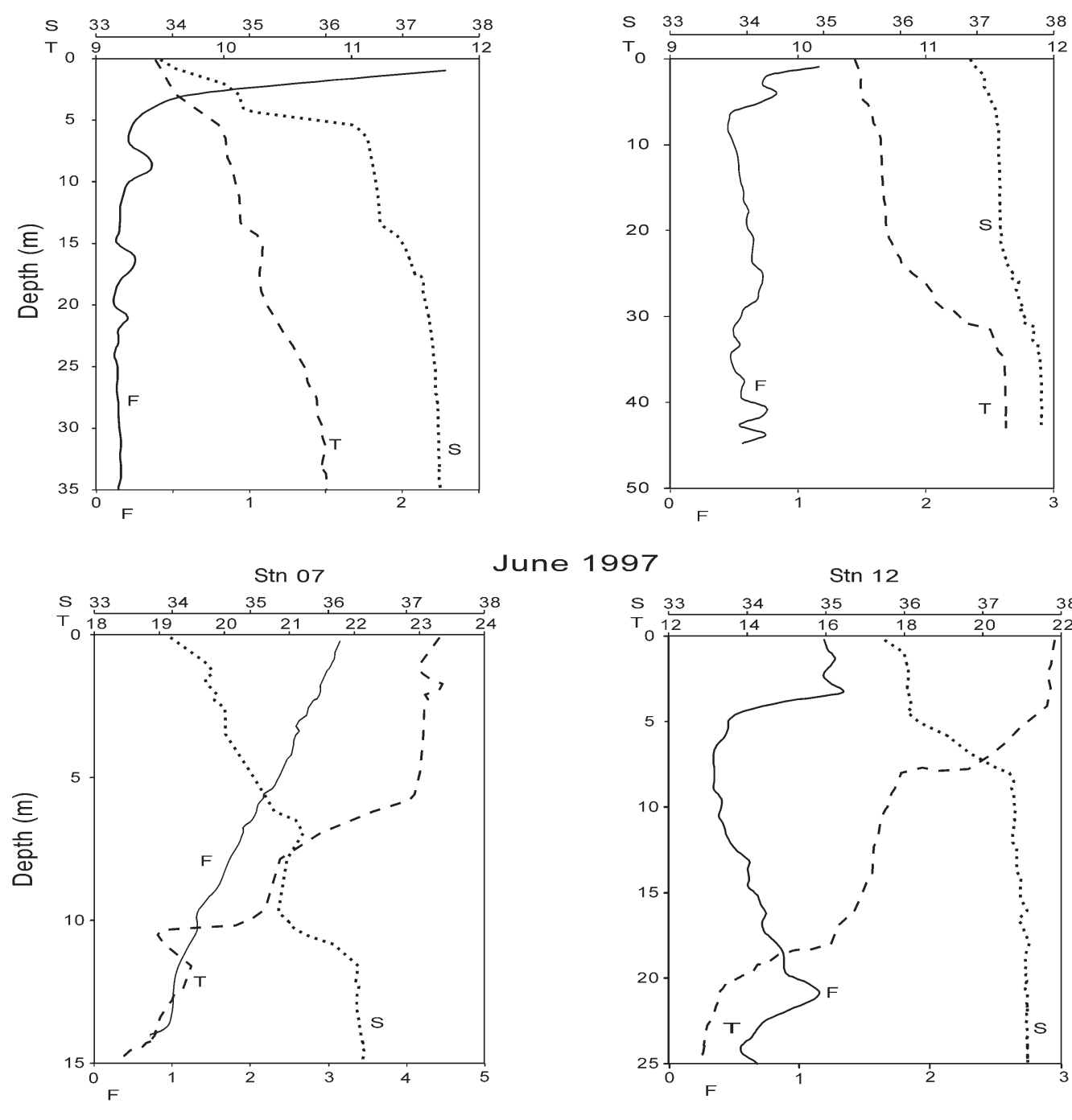

June 1997
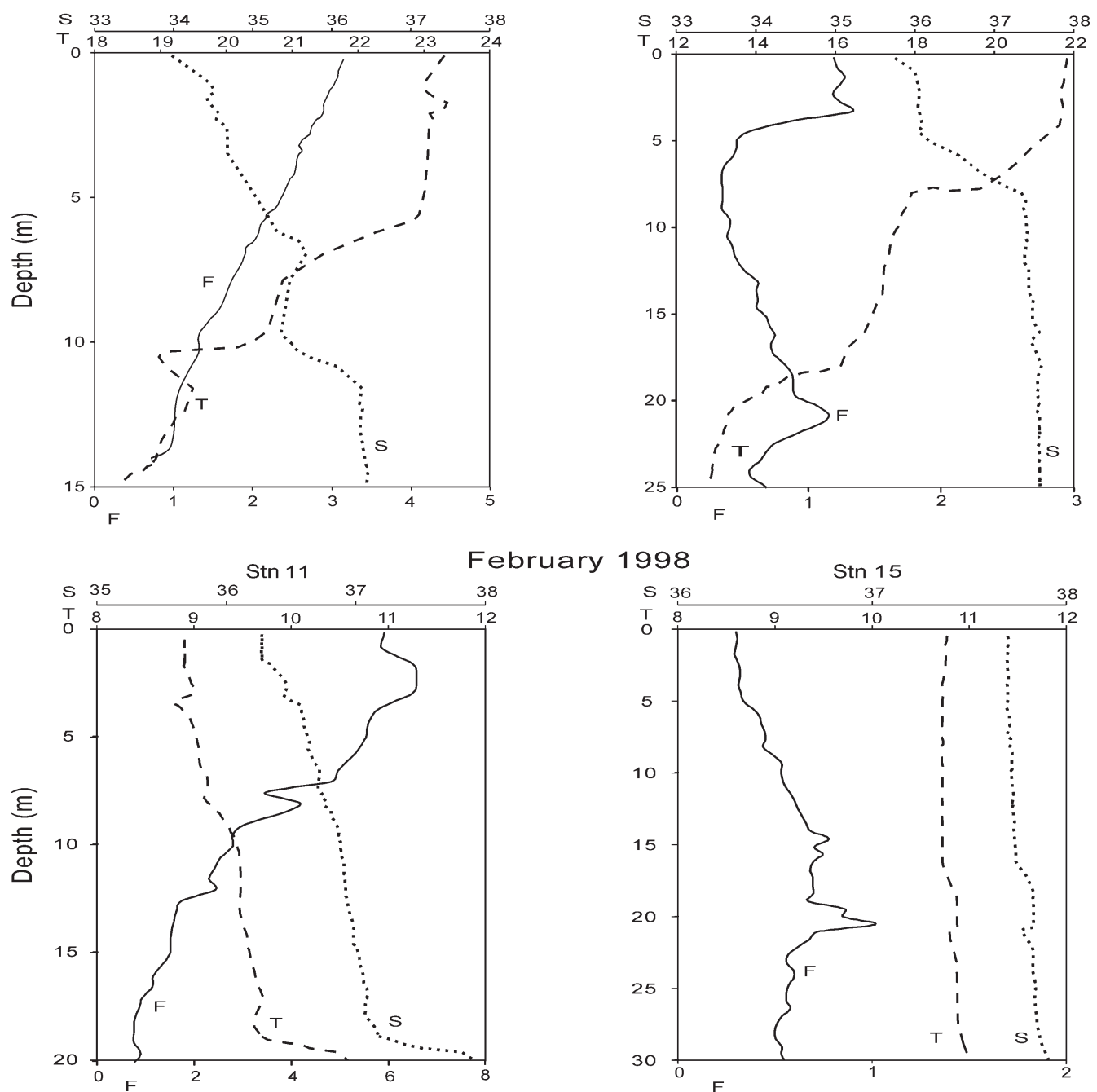

February 1998

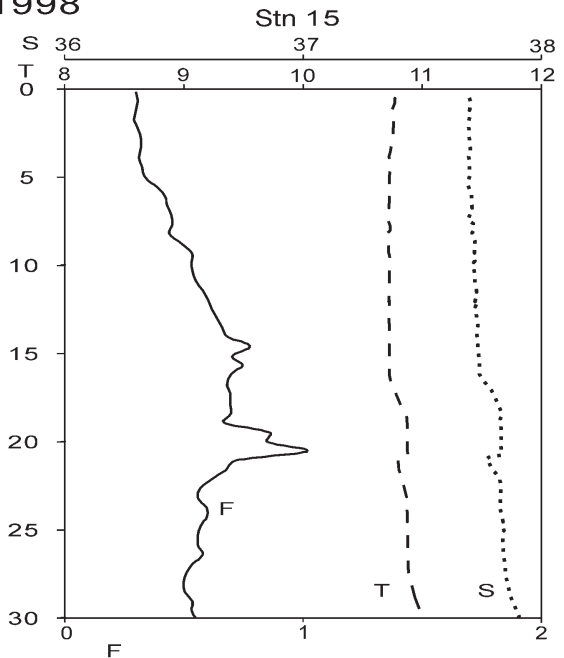

Fig. 2. Vertical profiles of temperature (T), salinity (S) and fluorescence (F) at selected inshore (left panels) and offshore (right panels) stations, with respect to the front, during bloom (February 1997 and 1998) and post-bloom (June 1997) conditions. Fluorescence values correspond to units whereby 1 Unit $=1 \mathrm{mg} \mathrm{m}^{-3}=1 \mathrm{\mu g} \mathrm{l}^{-1}$ chlorophyll $\mathrm{a}$ 

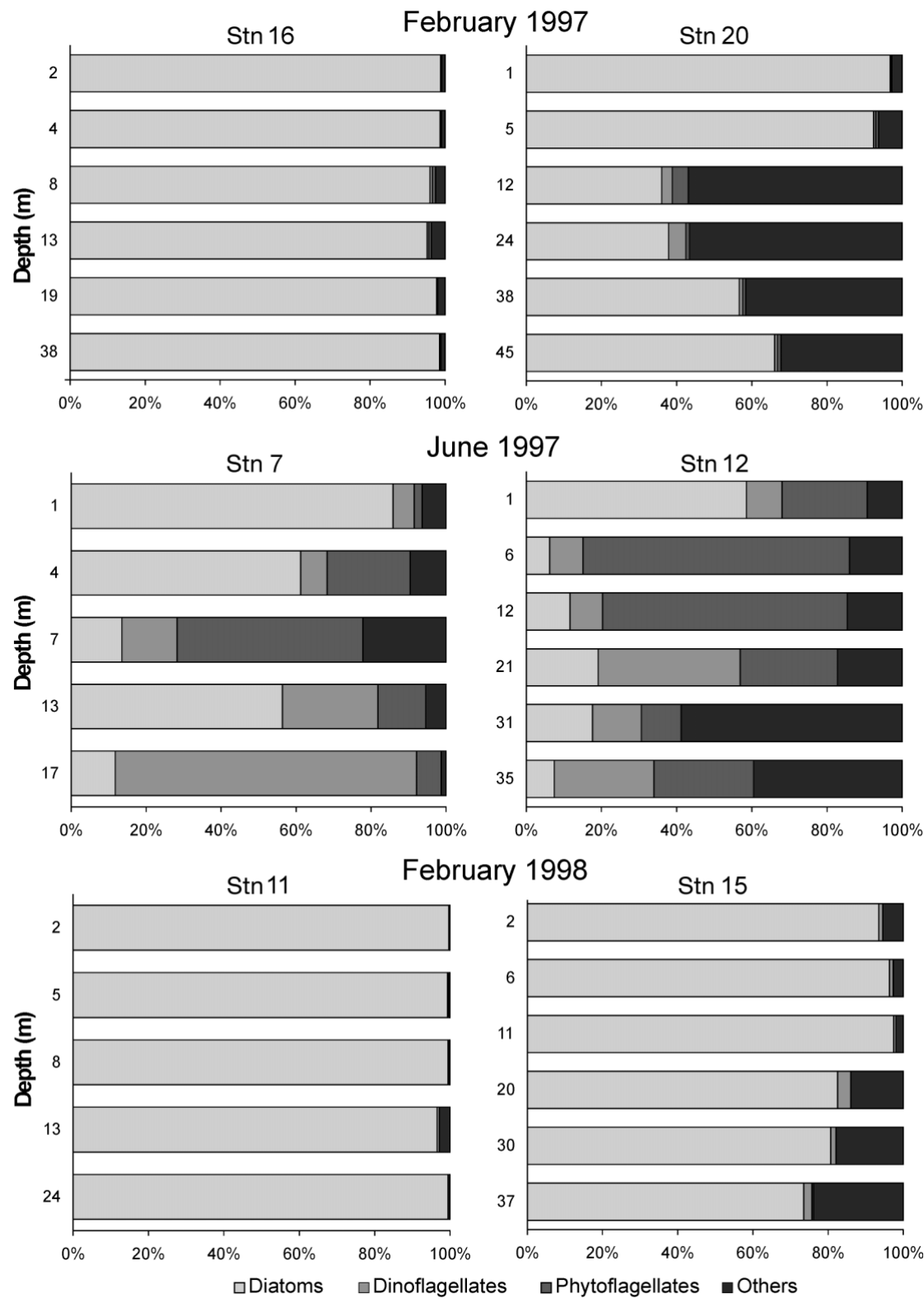

Fig. 3. Depth distribution and \% composition of different microplankton groups during bloom (February 1997 and 1998) and post-bloom (June 1997) conditions at selected inshore (left panels) and offshore (right panels) stations, with respect to the front

2002), whereas in the following February the bloom was almost entirely composed of $P$. delicatissima $(80.6 \%)$ (Cabrini et al. 2002, Socal et al. 2002). Other important groups in late winter were mainly undetermined dinoflagellates and phytoflagellates.

Both Skeletonema costatum and Pseudo-nitzschia delicatissima were mainly concentrated in the upper 10 to $20 \mathrm{~m}$ of the water column in the late winter of both years at both inshore and offshore stations (Fig. 4). Cell concentrations for these species at Stns 16 and 11 were about $2.5 \times 10^{6}$ cells $\mathrm{l}^{-1}$ for $S$. costatum in winter 1997 and $3 \times 10^{6}$ cells $1^{-1}$ for $P$. delicatissima in winter 1998. Concentrations were much lower at Stns. 20 and 15 (about $1.2 \times 10^{6}$ cells $\mathrm{l}^{-1}$ for $S$. costatum in winter 1997 and $6 \times 10^{4}$ cells ${ }^{-1}$ for $P$. delicatissima in winter 1998).

In June, diatoms represented an important component of the algal population only at more inshore stations, where they constituted about $50 \%$ of the algal population (data not shown). The dominant diatom species at the time were Chaetoceros decipiens and Dactyliosolen fragilissimus (Cabrini et al. 2002), which represented 57.3 and $23.0 \%$ at Stn 12 , and 46.4 and $41.1 \%$ at Stn 7, respectively. During this period, dinoflagellates (Prorocentrum micans, $P$. gracile and $P$. minimum) and undetermined flagellates together constituted over $>80 \%$ of the population at the offshore station (Stn 12) and $>40 \%$ at the inshore station (Stn 7). Both $S$. costatum and $P$. delicatissima were extremely rare or were absent from June samples. In this period, diatom cell numbers had dropped by more than 1 order of magnitude compared to late winter samples, with cell concentrations ranging from about $10^{4}$ to $10^{5}$ cells $1^{-1}$, depending on the species.

The copepod Acartia clausi was the most abundant copepod sampled in June, constituting $47.7 \%$ of the copepod population; low abundances were recorded in February 1997 (1.6\%) and $1998(1.8 \%)$. A previous study ranked this species no. 4 in terms of numerical importance for the entire Adriatic basin, with highest abundances in the North Adriatic (Hure et al. 1980). Fig. 5 shows the population structure for this species during the 3 cruises. The structure differed for February of both years; whereas in 1997 the population was strongly dominated by juvenile stages (Copepodite Stages CII to CV) of A. clausi $(55.1 \%)$, followed by females $(28.7 \%)$ and males $(16.2 \%)$, the following year juveniles (CII to CV) represented $31.3 \%$ of the population, females $47 \%$ and males $21.6 \%$. In June, the population had increased almost 5-fold, with juveniles now representing 39.6\%, females $39.2 \%$ and males $21.2 \%$ of the population.

In terms of spatial distribution, most females, males and copepodids of Acartia clausi were concentrated in the upper $10 \mathrm{~m}$ in February of both years (Fig. 6). 
These waters were the most stratified, richest in chlorophyll (Fig. 2), and dominated by diatoms (Fig. 4). In June, the picnocline was lower $(25 \mathrm{~m})$, and the $A$. clausi population was more evenly distributed within this water column which also corresponded to the richest area for algal biomass (Fig. 2).

Egg production rates of Acartia clausi were highest during the diatom bloom in both years, with 10.6 and 18.4 eggs female ${ }^{-1} \mathrm{~d}^{-1}$ in 1997 and 1998, respectively (Fig. 7). Much lower values (6.2 eggs female $\mathrm{e}^{-1} \mathrm{~d}^{-1}$ ) were recorded in June 1997. However, the most dramatic differences between diatom bloom and post-bloom conditions were in egg hatching viability, with mean values of 15.4 and $16.1 \%$ hatching success in February 1997 and 1998, respectively, as opposed to 89.1\% in June 1997.

Interestingly, the number of fecal pellets was higher in late winter of both years (14.3 and 6.8 fecal pellets female $\mathrm{e}^{-1} \mathrm{~d}^{-1}$ in February 1997 and 1998, respectively), indicating active feeding on diatoms, as also inferred by high egg production rates. However, in terms of hatching viability, the low number of fecal pellets produced in June (0.61 fecal pellets female ${ }^{-1} \mathrm{~d}^{-1}$ ) was accompanied by the best egg viability. Total egg production of Acartia clausi was much greater in June due to the high number of females in this period (Fig. 8). A mean TEP value of 863 eggs $\mathrm{m}^{-3} \mathrm{~d}^{-1}$ was estimated in this period compared to 17.6 eggs $\mathrm{m}^{-3} \mathrm{~d}^{-1}$ in February 1997 and 140.6 eggs $\mathrm{m}^{-3} \mathrm{~d}^{-1}$ in February 1998. If we also consider the total number of nauplii recruited, which takes into consideration not only the product of egg production rates and female numbers but also the hatching viability of eggs, these values were impressively high in June (mean $=790.2$ nauplii $\mathrm{m}^{-3} \mathrm{~d}^{-1}$ ) compared to February 1997 (mean = 2.8 nau-
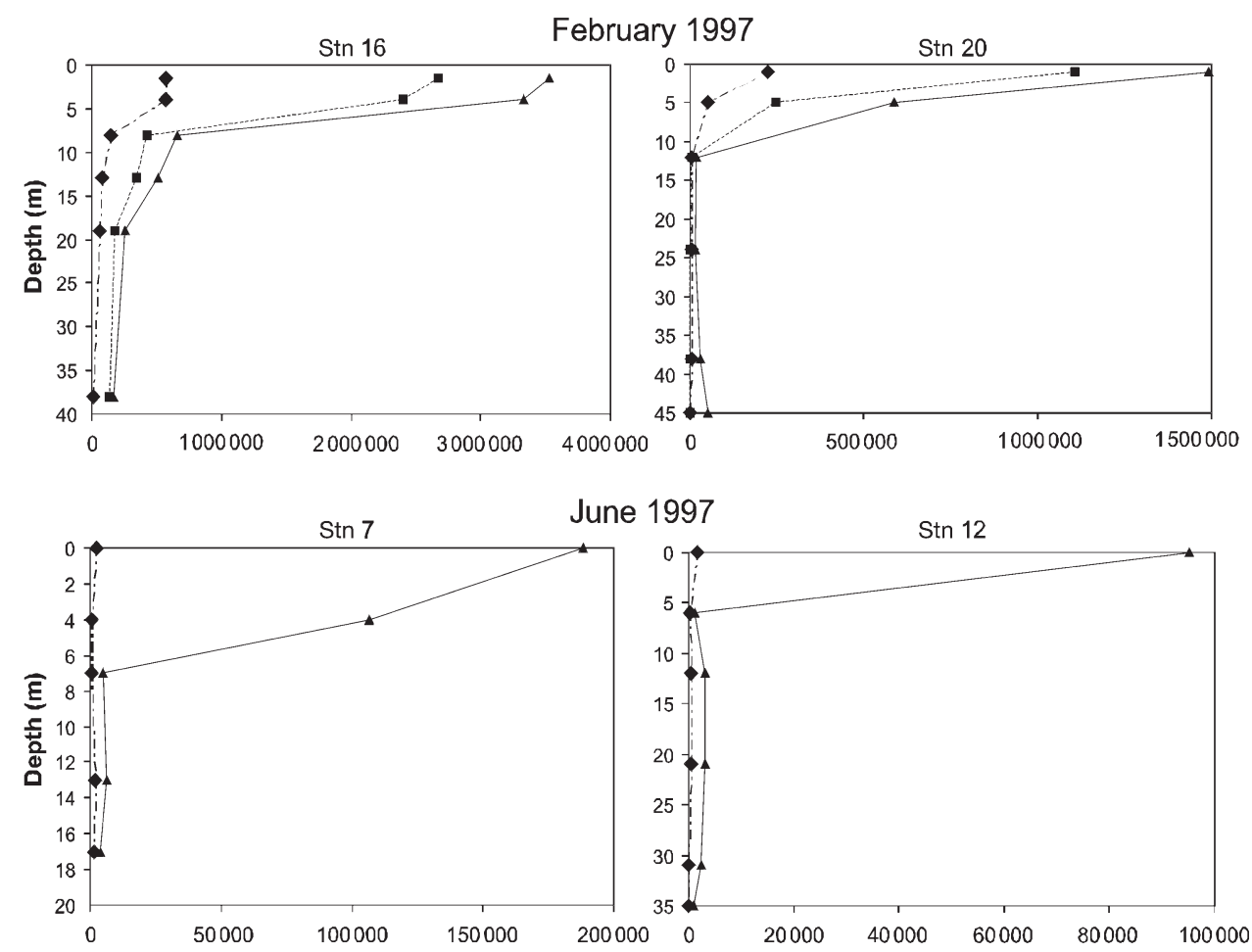

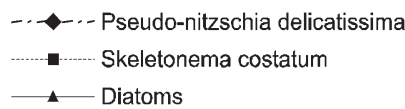

$\_$Diatoms

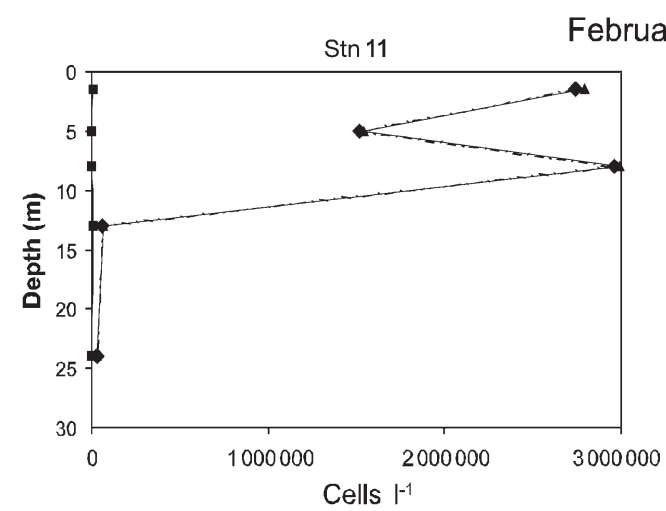

February 1998

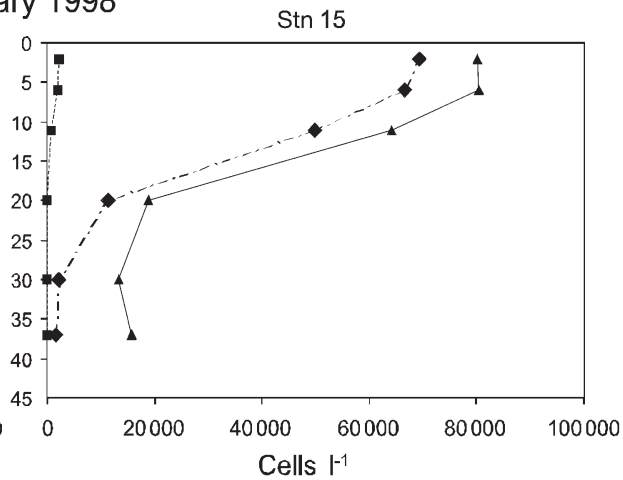

Fig. 4. Skeletonema costatum and Pseudo-nitzschia delicatissima. Depth distribution of total diatoms and the 2 diatom species during bloom (February 1997 and 1998) and post-bloom (June 1998) conditions at selected inshore (left panels) and offshore (right panels) stations, with respect to the front 

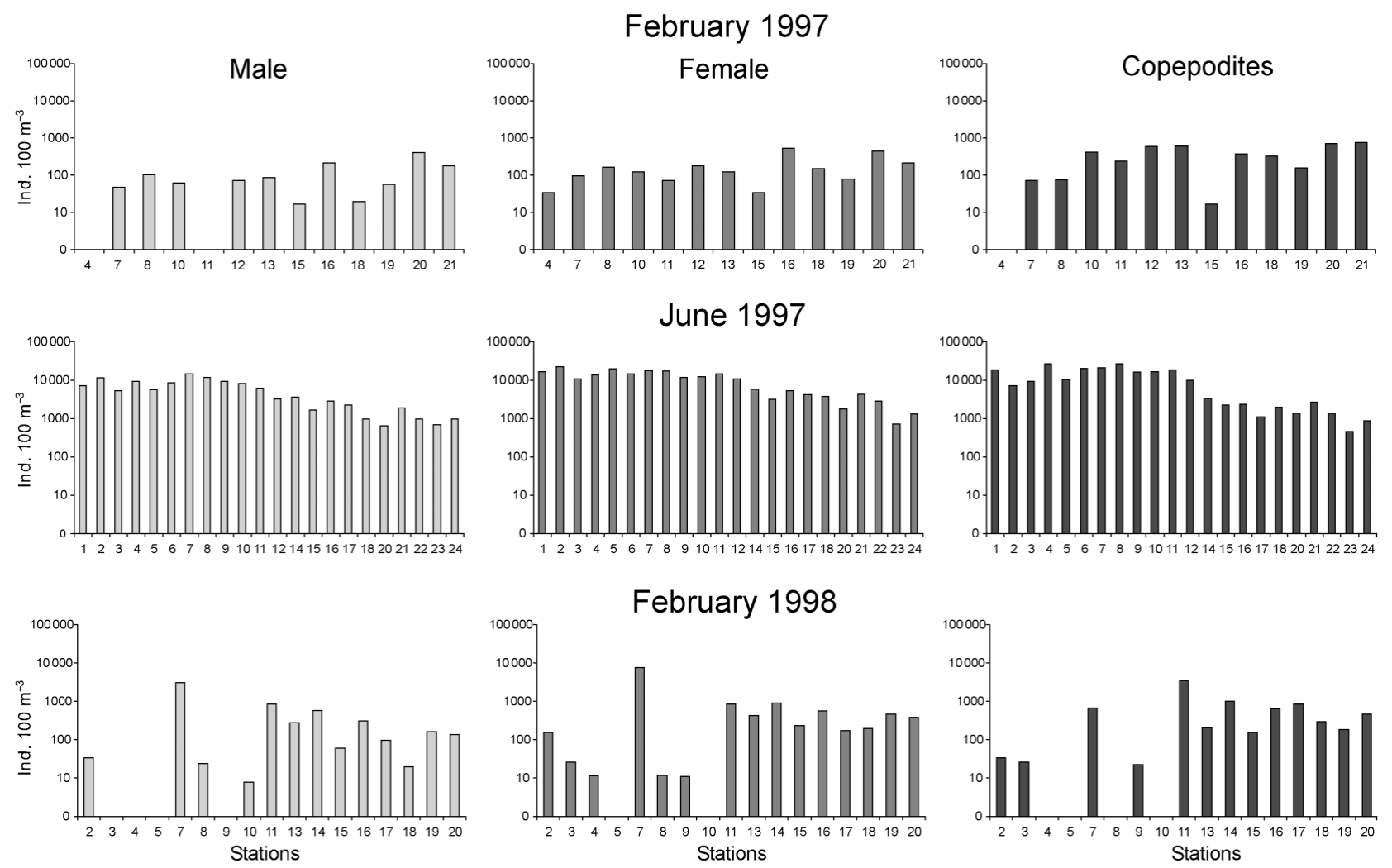

Fig. 5. Acartia clausi. Population structure and numbers of males, females and copepodites (CII to CV) at all stations sampled during bloom (February 1997 and 1998) and post-bloom (June 1997) conditions

plii $\mathrm{m}^{-3} \mathrm{~d}^{-1}$ ) and February 1998 (mean = 15.6 nauplii $\left.\mathrm{m}^{-3} \mathrm{~d}^{-1}\right)$.

The population structure was also determined for Calanus helgolandicus in February 1998, when the population consisted mainly of copepodids (CI to CV), at both inshore $(93.6 \%)$ and offshore $(89.7 \%)$ stations, followed by females $(4.8 \%)$ and males $(3.6 \%)$. This species was much less abundant than Acartia clausi, representing only $0.82 \%$ of total copepod numbers in February 1998. In a previous study, Calanus helgolandicus ranked No. 12 in terms of numerical importance (Hure et al. 1980), supporting the present findings that this species is not dominant in this area. Fig. 9 illustrates the depth profiles of males, females and copepodids for this species in February 1998 in the North Adriatic Sea.

The mean EPR for Calanus helgolandicus in February 1998 was low (9.7 eggs female ${ }^{-1} \mathrm{~d}^{-1}$ ), with only $6.5 \%$ hatching viability (Fig. 10), which was even lower that that for Acartia clausi in the same period. TEP $\left(\right.$ mean $=54$ eggs $\left.\mathrm{m}^{-3} \mathrm{~d}^{-1}\right)$ and TNR $($ mean $=$ 4.7 nauplii $\mathrm{m}^{-3} \mathrm{~d}^{-1}$ ) for $C$. helgolandicus were somewhat lower than for A. clausi in the same year. Fecal pellet numbers for $C$. helgolandicus were double (15.9 fecal pellets female ${ }^{-1} \mathrm{~d}^{-1}$ ) those for A. clausi (6.8 fecal pellets female $\mathrm{f}^{-1} \mathrm{~d}^{-1}$ ) in the same period.

\section{DISCUSSION}

The late-winter diatom bloom in the North Adriatic Sea inhibited the population growth of both Acartia clausi and Calanus helgolandicus. Reduced population growth in A. clausi was not due to a diminution in fecundity since egg production values in 1998 were elevated and comparable to peak EPR for this species in other Mediterranean coastal (Ianora \& Buttino 1990) and offshore (Calbet et al. 2002) areas. However, although EPR was higher during the blooms in 1997 and 1998 (10.6 and 18.4 eggs female $\mathrm{e}^{-1} \mathrm{~d}^{-1}$, respectively) compared to June (6.2 eggs female $\left.{ }^{-1} \mathrm{~d}^{-1}\right)$, the number of adult females in this period was very low (173 females $100 \mathrm{~m}^{-3}$ in 1997 and 712 females $100 \mathrm{~m}^{-3}$ in 1998) compared to 9827 females $100 \mathrm{~m}^{-3}$ in June 1998. Hence, TEP for the entire A. clausi population was 49 and 6 times lower during the diatom blooms in 1997 and 1998, respectively, compared to later in the year. Variability may have depended on differences in diatom species composition. The bloom in 1997 was mostly dominated by Skeletonema costatum (66.3\%) and Pseudo-nitzchia delicatissima (23.2\%), whereas the following year the bloom was almost entirely composed of $P$. delicatissima $(80.6 \%)$, as already reported 

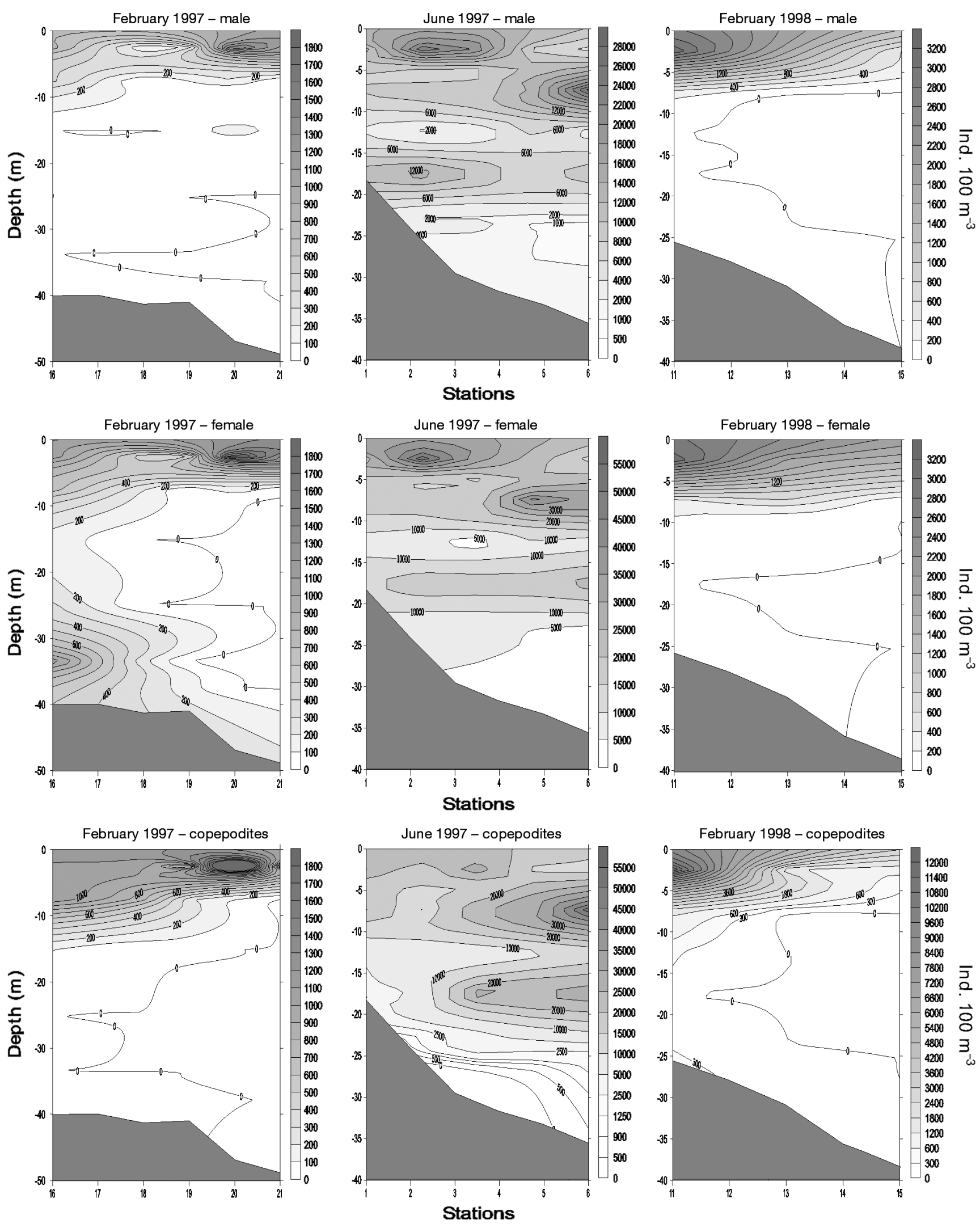

Fig. 6. Acartia clausi. Depth distribution and numbers of males, females and copepodites (CII to CV) at all stations sampled during bloom (February 1997 and 1998) and post-bloom (June 1997) conditions 

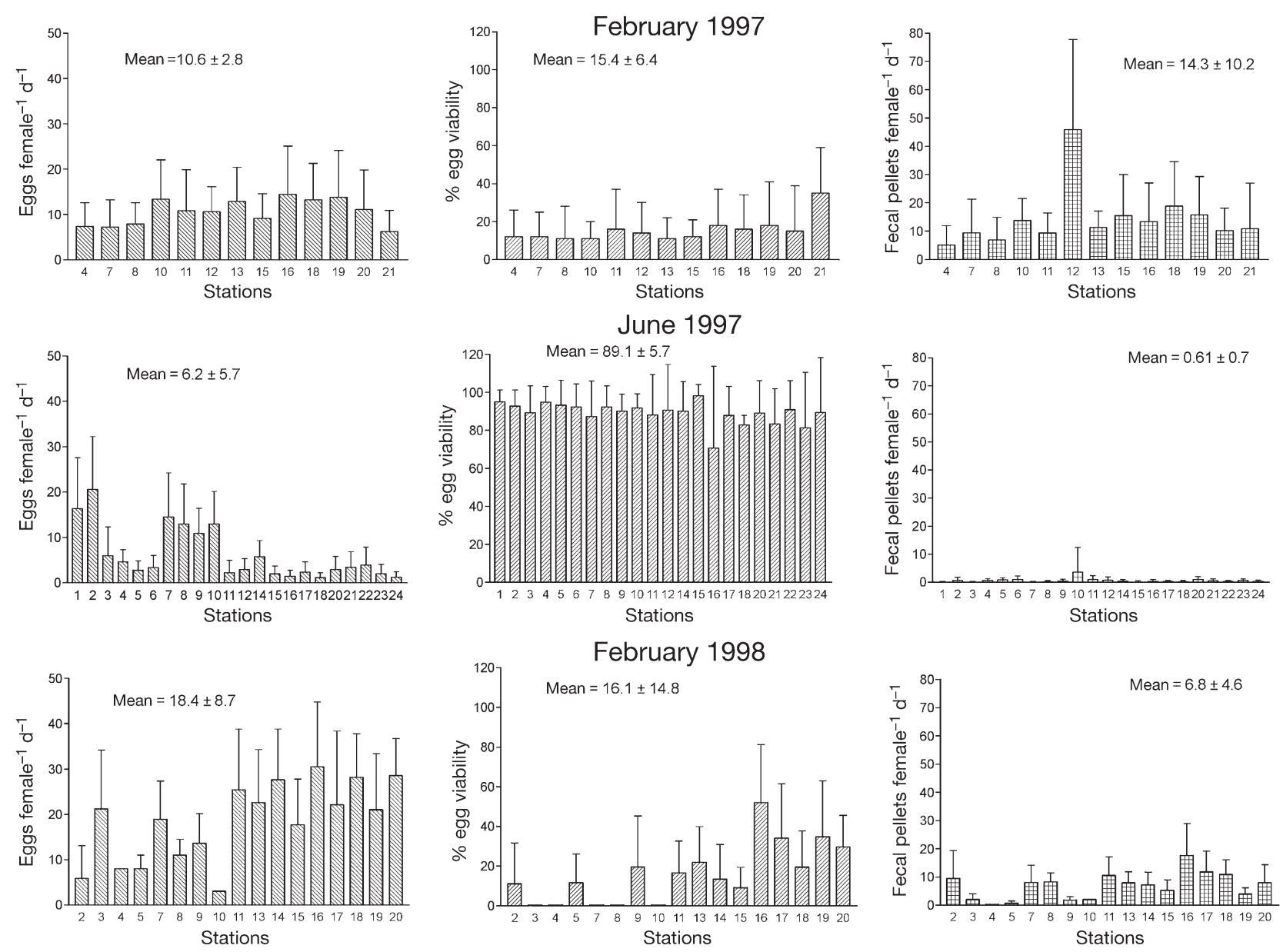

Fig. 7. Acartia clausi. Egg production rate (eggs female $\left.\mathrm{e}^{-1} \mathrm{~d}^{-1}\right), \%$ egg viability and fecal pellet production rate (fecal pellets female $\mathrm{e}^{-1} \mathrm{~d}^{-1}$ ) at all stations sampled during bloom (February 1997 and 1998) and post-bloom (June 1997) conditions (modified from Miralto et al. 2002). Differences between February 1997, June 1997 and February 1998 were highly significant (egg production: $\mathrm{p}<0.0001 \mathrm{r}^{2}=0.4$; egg hatching success: $\mathrm{p}<0.0001 \mathrm{r}^{2}=0.9$; fecal pellet production: $\mathrm{p}<0.0001 \mathrm{r}^{2}=0.5$; 1 -way ANOVA)

in a previous study (Miralto et al. 1999) even though the data were not shown at the time. Several laboratory studies have shown that $S$. costatum reduces both fecundity and hatching in A. clausi (Ban et al. 1997, Ianora et al. 2003), supporting the present findings that EPR was lower when the bloom was dominated by S. costatum.

Low population growth of Acartia clausi in winter was not due to lower feeding activity. Although we have no direct evidence that $A$. clausi was in fact ingesting diatoms at the time, the number of fecal pellets produced was much higher during the blooms than afterwards. Fecal pellet counts have often been used in laboratory egg production studies to indicate higher or lower copepod-feeding activity on different algal diets (Uye 1996, Lacoste et al. 2001, Turner et al. 2001). The higher fecal pellet counts in the present field study indicate that copepods were feeding actively during the blooms. Since most of the phytoplankton during the blooms was composed of diatoms (>90\% at offshore and $>40$ to $95 \%$ at inshore stations), we infer that A. clausi was feeding mostly on diatoms at the time due to little other choice, and since laboratory studies have shown that copepods willingly ingest diatoms.

For this copepod species, there was an apparent decoupling between egg production and fecal pellet production, and between these 2 rates and hatching success. Higher fecal pellet production did not always induce higher egg production rates. In turn, both rates were unrelated to hatching viability, confirming recent laboratory findings of decoupling of these 3 parameters (Turner et al. 2001). Thus, highest fecal pellet production rates in February 1997 supported lower EPR compared to the following year, and lowest fecal pellet production rates supported highest egg viability for this species, indicating that the food conditions promoting high egg production differed from those inducing high hatching viability. 


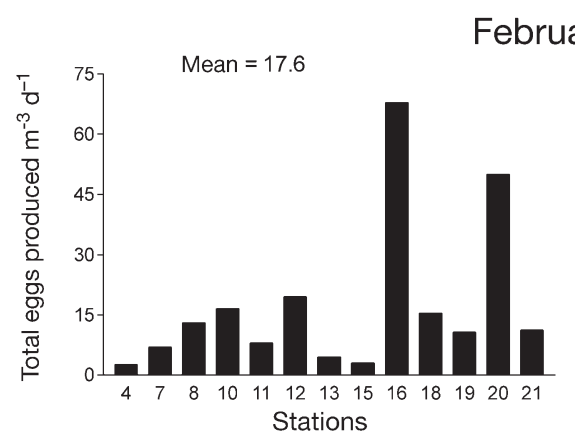

June 1997
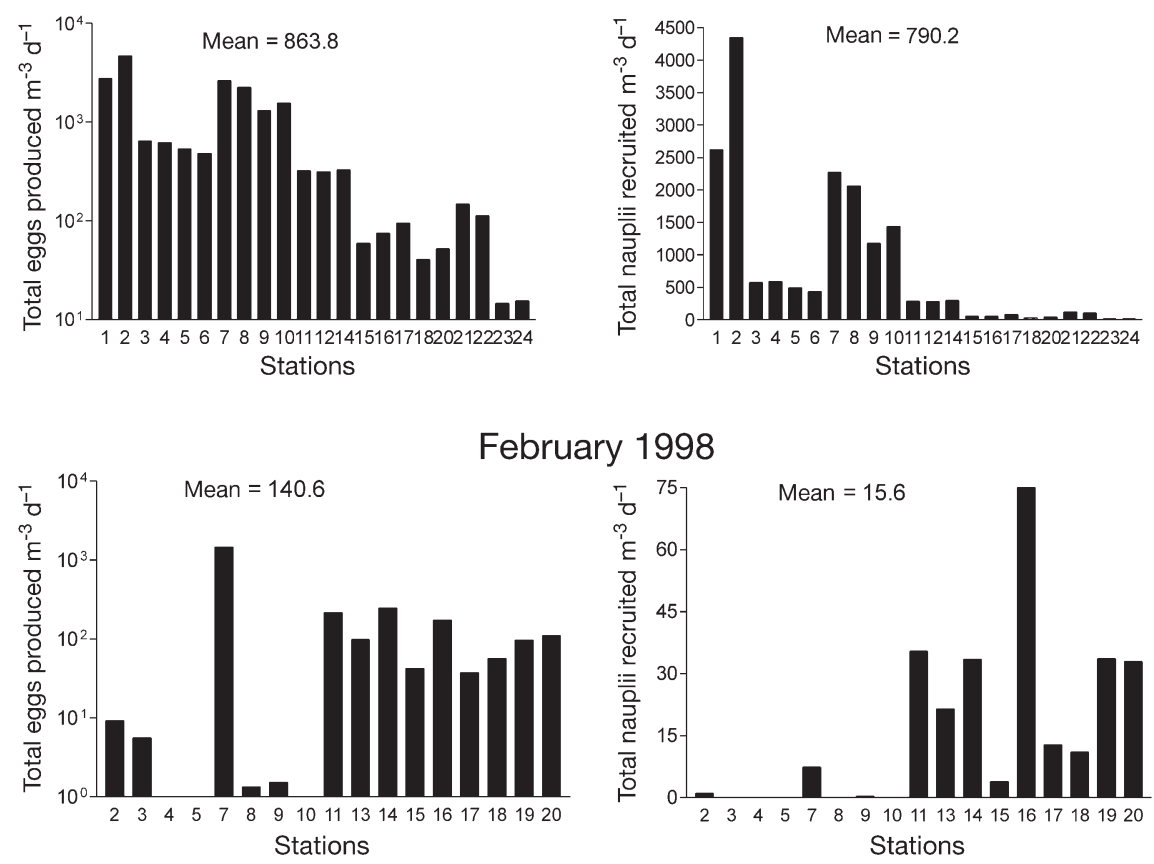

Fig. 8. Acartia clausi. Total egg production rate $($ egg production rate $[\mathrm{EPR}] \times$ total number of females $\mathrm{m}^{-3}$ ) and total nauplii recruited (EPR $\times$ total number of females $\mathrm{m}^{-3} \times \%$ egg viability) at all stations sampled during bloom (February 1997 and 1998) and post-bloom (June 1997) conditions. Differences between February 1997, June 1997 and February 1998 were significant (total egg production rate: $\mathrm{p}=0.005$ $\mathrm{r}^{2}=0.2$; total nauplii recruited: $\mathrm{p}=0.001 \mathrm{r}^{2}=0.22 ; 1$-way ANOVA)

the proportion of males (which was about half that of females in this period) indicates that this hypothesis is unlikely. Furthermore, most females were producing at least some fertilised eggs suggesting that remating had occurred. It is also unlikely that food characteristics such as nutrient deficiency were responsible for reduced egg viability, since diatoms are known to be nutritive food sources containing high levels of fatty acids (Brett \& Müller-Navarra 1997) which are considered essential for zooplankton larval growth (Müller-Navarra 1995, Gulati \& Demott 1997).

On the other hand, several diatom species, including Skeletonema costatum and Pseudo-nitzschia delicatissima, have been shown to produce several reactive unsaturated aldehydes that have adverse effects on copepod embryogenesis (Miralto et al. 1999); these derive from eicosanoic (C20) fatty acids seconds after mechanical damage by diatom cells such as that which occurs during feeding by predators (Pohnert 2000). It has been suggested that such compounds serve as chemical defences that potentially sabotage future generations of herbivores. The present findings indicate that reduced hatching viability may also occur in situ concomitant with the blooming of certain diatom species such as $S$. costatum and P. delicatissima. These diatoms have been shown to produce such aldehydes (Miralto et al. 1999) and also new aldehydes, other than those already

The main factor responsible for reduced population recruitment rates of Acartia clausi was probably low hatching viability. Although advective losses cannot be rejected, hatching viability during the blooms of 1997 and 1998 was only 15.4 and $16.1 \%$, respectively, as previously also reported by Miralto et al. (1999, 2002). TNR was 282 and 50 times lower during the blooms of 1997 and 1998, respectively, compared to June, indicating that very few offspring were being recruited during the diatom blooms. The causes for reduced hatching viability may have been multiple. A. clausi females may have been unripe in February and therefore spawning mostly unfertilised eggs, even though described (d'Ippolito et al. 2002b, Pohnert et al. 2002), with similar biological activity. Laboratory studies have already shown that the Adriatic clone of S. costatum induces hatching failure in Mediterranean populations of the copepods Acartia clausi and Calanus helgolandicus (Ianora et al. 2003) and in Temora stylifera (Ceballos \& Ianora in press).

The diatom blooms in the North Adriatic Sea were very strong, with diatoms representing on average $>90 \%$ of the phytoplankton at inshore and >40 to $95 \%$ at offshore stations, and with concentrations reaching

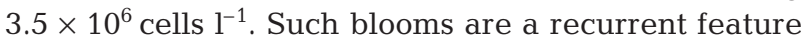
in this area, persisting for several weeks to months in 


\section{February 1998}
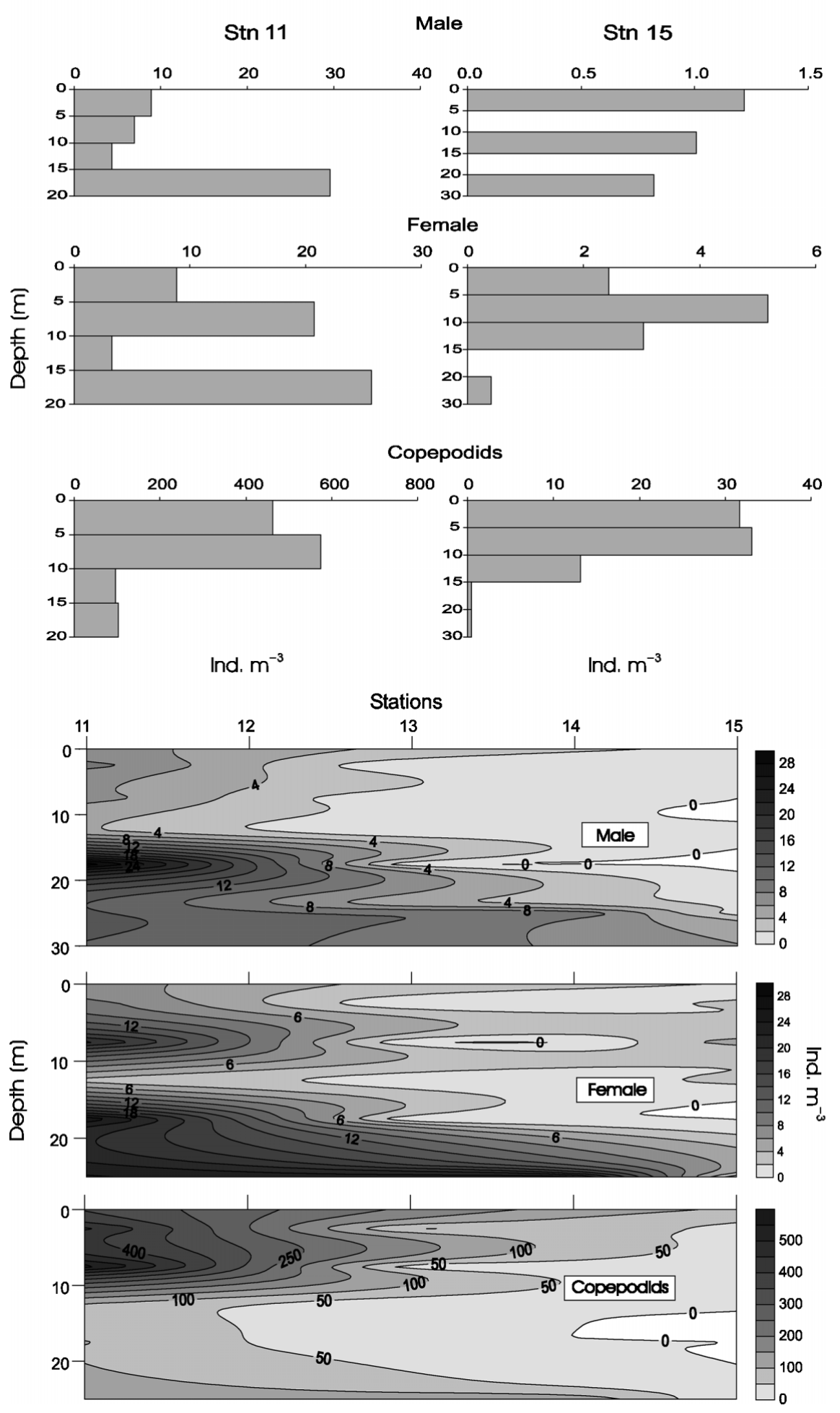

Fig. 9. Calanus helgolandicus. Stations sampled during bloom conditions in February 1998. (Top) Population structure and numbers of males, females and copepodites (CII to CV) at different depths at a representative inshore (Stn 11) and offshore (Stn 15) station with respect to the front. (Bottom) Depth distributions of males, females and copepodites (CII to CV) late winter (Vollenweider et al. 1992). The diatom blooms in 1997 and 1998 consisted mainly of Skeletonema costatum and Pseudo-nitzschia delicatissima, but the composition of blooms may vary from year to year. Fonda Umani (1996) reported that diatoms are the most important phytoplankton group in the North Adriatic Sea, having 2 population maxima, one in spring and the other in summer. The main species that dominate these blooms are Nitzschia seriata, S. costatum, Thalassiosira spp., Cyclotella spp. and smaller species of the genus Chaetoceros. The blooms in 1997 and 1998 seem to have differed from preceding years in that they occurred earlier, in mid-winter, and were almost exclusively characterised by $S$. costatum and another species $(P$. delicatissima) not mentioned by Fonda Umani (1996).

There is recent evidence that diatom blooms do not always adversely affect hatching viability of copepods at sea. Pond et al. (1996) found that hatching viability for Calanus helgolandicus was consistently high, with a seasonal mean of $83 \%$, at a coastal station in the western English Channel off Plymouth during January to September 1993, and that hatching success was not correlated with the abundance of diatoms. Irigoien et al. (2002) also did not observe a negative relationship between copepod egg hatching success and either diatom biomass or dominance in the microplankton from 12 globally distributed areas. Our present results confirm that diatoms do not always impair copepod embryogenesis. For example, in June diatoms still constituted about $50 \%$ of the phytoplankton population at inshore stations, but the hatching viability of Acartia clausi was $89.1 \%$. The diatom species in this period had shifted to a dominance of Chaetoceros decipiens and Dactyliosolen fragilissimus, 2 species that may not produce the unsaturated aldehydes described for Skeletonema costatum and Pseudo-nitzschia delicatissima, or produce others with less toxic effects on copepod embryogenesis. Pohnert et al. (2002) showed that not all diatoms were capable of produc- 

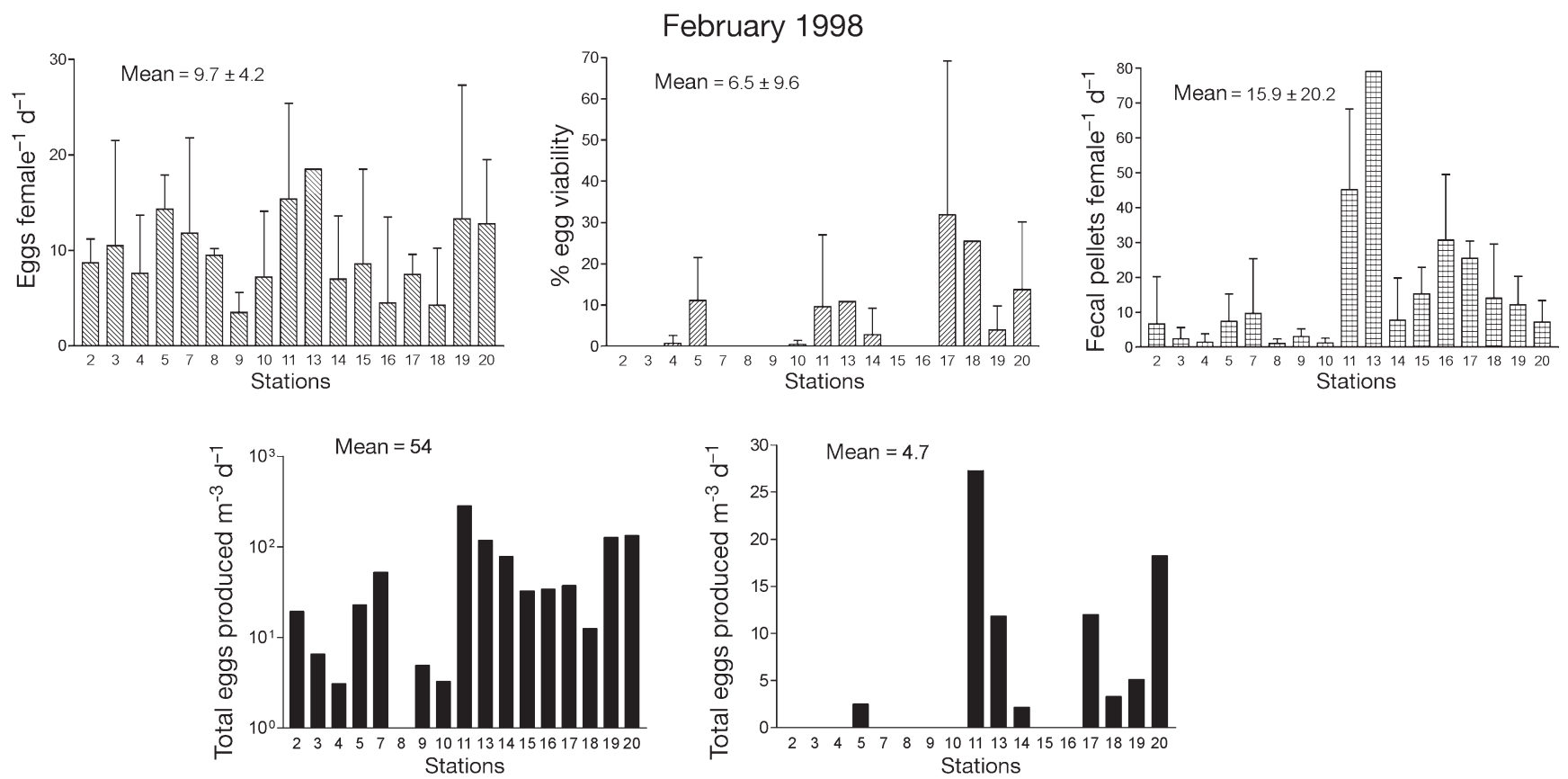

Fig. 10. Calanus helgolandicus. Egg production rate, \% egg viability, fecal pellet production rate, total egg production rate $\mathrm{EPR} \times$ total number of females $\mathrm{m}^{-3}$ ) and total nauplii recruited (EPR $\times$ total number of females $\mathrm{m}^{-3} \times \%$ egg viability) at all stations sampled during bloom in February 1998

ing reactive aldehydes such as those described by Miralto et al. (1999). For example, 2 strains of Thalassiosira rotula from different geographic areas differed in their inhibitory effect on copepod egg hatching success, with the less inhibitory strain unable to produce reactive unsaturated aldehydes. Pohnert et al. (2002) suggested that the inhibitory properties of diatomderived aldehydes depended on the reactive structural element $(\alpha, \beta, \gamma, \delta$-unsaturated aldehyde), common to some but not all diatoms examined. Molecules of this kind are often associated with toxicity (Refsgaard et al. 2000). Using immunofluorescent dyes specific for DNA and $\alpha$-tubulin subunits, Buttino et al. (1999) showed that microtubules of newly spawned sea urchin embryos were de-polimerised when exposed to watersoluble extracts of the diatom $T$. rotula, and were therefore unable to undergo normal cleavage. Both crude extracts of the diatom Skeletonema costatum and the purified aldehyde decadienal were found to inhibit fertilisation, embryogenesis and hatching success in broadcast-spawning polychaetes and the echinoderms (Caldwell et al. 2002). Tosti et al. (in press) showed that decadienal also affected actin microtubule reorganisation and inhibited the fertilisation current which is activated upon interaction with the spermatozoan in ascidian oocytes. Hence, diatomderived unsaturated aldehydes seem to act through the disorganisation of primary fertilisation events and microfilament network during development.
Alternatively, Acartia clausi may have had a more ample choice of alternate food items in June, therefore diluting the negative effects of diatom aldehydes sensu Turner et al. (2001). This dilution effect may be a major reason why Irigoien et al. (2002) did not find a negative effect of diatoms on hatching success in the field. In our study, diatoms constituted $90 \%$ of the microplankton in both years, and the bloom was composed mainly of 2 species, both of which are known to produce aldehydes. In the study conducted by Irigoien et al. (2002), most of the data on hatching viability refer to areas where diatoms constituted $<50 \%$ of the microplankton. Copepods may therefore have fed on alternate food items, thereby diluting the negative effects of diatom-derived aldehydes. Notwithstanding, even the results presented by Irigoien et al. (2002) showed that this effect can at times occur at sea where, in at least $25 \%$ of the cases he recorded, hatching was $<80 \%$ and in $8 \%$ of the cases it was $<50 \%$.

There was reduced population growth in Calanus helgolandicus during the 1998 bloom. In this case the most likely causes were a combination of low egg production rates and hatching viability, and depressed adult female numbers. For example, the EPR of C. helgolandicus were somewhat lower (9.7 eggs female ${ }^{-1}$ $\mathrm{d}^{-1}$ ) than those reported elsewhere. Offshore Roscoff (France) in the English Channel, Laabir et al. (1998) estimated that during summer and autumn fecundity was on average 15 eggs female ${ }^{-1} \mathrm{~d}^{-1}$, with a maximum 
fecundity of around 20 to 30 eggs female $\mathrm{e}^{-1} \mathrm{~d}^{-1}$ from May to July, and in winter, when the water temperature was $10^{\circ} \mathrm{C}$, fecundity was arrested. Irigoien et al. (2000) reported similar findings off Plymouth (UK) in the English Channel, except that maximum rates (20 to 30 eggs female ${ }^{-1} \mathrm{~d}^{-1}$ ) occurred from February to August, with a very low EPR $\left(<5\right.$ eggs female $\left.{ }^{-1} \mathrm{~d}^{-1}\right)$ during the rest of the year. Hence, we can infer that C. helgolandicus was not producing at the maximal rates known for this species in this period. Temperature conditions in February $\left(9\right.$ to $\left.11^{\circ} \mathrm{C}\right)$ were similar to those reported for surface waters off Roscoff, and may have been one of the causes for reduced fecundity. Alternatively, the bloom conditions may not have been optimal for promoting high EPR rates in this species compared to Acartia clausi, which reached its maximum EPR in the same period. Since the adult female population size of $C$. helgolandicus was also lower than that of A. clausi in this period, the TEP for C. helgolandicus were about 2.6 times lower than for $A$. clausi. Together with hatching viability, which was extremely low in this period $(6.5 \%)$, this resulted in recruitment rates (TNR) for $C$. helgolandicus that were 3.3 times lower than those for A. clausi.

It is interesting to observe the spatial distributions of Acartia clausi and Calanus helgolandicus during the blooms in February. For example, A. clausi females, males and juveniles were concentrated mainly at the surface in proximity to the bloom. In June, on the other hand, the population was more scattered throughout the water column even though there were still dense patches of individuals at the surface, again in correspondence with the bloom or with higher fluorescence values (Gugliemo et al. 2002). In contrast, C. helgolandicus adult females and males were mainly concentrated below the bloom in February 1998, with only larval stages residing at the surface in proximity to the bloom. Most females contained large amounts of body lipids in this period. Fecal pellet counts were relatively low (15.9 fecal pellets female $\mathrm{e}^{-1} \mathrm{~d}^{-1}$ ) compared to those in other periods, when values as high as 62.8 fecal pellets female ${ }^{-1} \mathrm{~d}^{-1}$ were recorded for this species (A. Miralto unpubl. data). Female C. helgolandicus may therefore have been partially fueling egg production by using body reserves, as previously reported for C. finmarchicus (e.g. Niehoff et al. 2002).

Copepod secondary production has rarely been measured in the ocean, and there is still much concern as to what methods to adopt for its measurement (Hirst \& McKinnon 2001), especially for lipid-storing copepods such as Calanus species, in which growth is not equivalent for all stages (Campbell et al. 2001). Poulet et al. (1995a) suggested that estimation of production and recruitment could be quantified based on the measurement of 3 variables: $E=$ fecundity of females, $B f=$ biomass of females, $V=$ hatching success; and the expression of 2 equations: $P=E \times B_{f}$ for production and $R=E \times B_{f} \times V$ for recruitment. We have adopted this method to calculate total egg production rates (TEP) and total naupliar recruitment rates (TNR) in the North Adriatic Sea, and now compare the values we report here with those of Poulet et al. (1995b) for C. helgolandicus off Roscoff in the English Channel. Since neither study measured changes in weight of adult females, comparisons only provide estimates of potential recruitment rates during bloom and post-bloom conditions in a highly productive system such as the North Adriatic Sea and a highly mixed coastal system in the western English Channel. Comparing Atlantic and Mediterranean C. helgolandicus populations, values in February in the North Adriatic (4.7 nauplii $\mathrm{m}^{-3} \mathrm{~d}^{-1}$ ) were somewhat higher than in winter off Roscoff (1.85 nauplii $\mathrm{m}^{-3} \mathrm{~d}^{-1}$ ). Comparing the summer populations in these 2 areas, we estimate that production rates were 16.5 times higher in Acartia clausi populations in the Adriatic Sea (790.2 nauplii $\mathrm{m}^{-3} \mathrm{~d}^{-1}$ ) compared to C. helgolandicus populations off Roscoff (47.7 nauplii $\mathrm{m}^{-3} \mathrm{~d}^{-1}$ ), confirming that the North Adriatic is a highly productive coastal region.

The present findings highlight the need to quantify hatching viability of copepods in the field, since variability in copepod recruitment will largely depend on the rate of production of viable eggs rather than fecundity per se. Unfortunately, until now, most studies have conducted only egg production measurements, assuming that all of the eggs spawned by copepods will develop to hatching. Our findings reveal that these 2 processes may be uncoupled, and that the environmental conditions promoting high fecundity in copepods may not necessarily be the same as those inducing high hatching viability. They also reveal that hatching viability can plummet, as during the diatom blooms in February 1997 and 1998 in the North Adriatic Sea, compromising the entire copepod cohort spawned during the bloom, and further emphasising the need to quantify egg viability in routine egg production studies.

Our data also indicate that the bulk of annual recruitment in the North Adriatic Sea occurs in the post-bloom phase, since the mixed community that succeeds the bloom is probably a better food source for copepod embryogenesis. They indicate that when diatom blooms are composed of certain species such as Skeletonema costatum and Pseudo-nitzschia delicatissima, which produce reactive aldehydes that compromise copepod hatching viability (Miralto et al. 1999), the effects can be disastrous in terms of population recruitment rates. On the other hand, not all diatoms seem to have toxic effects on egg hatching viability. 
Acknowledgements. We thank G. Arena for his help in data and graphic elaborations and M. Cabrini for phytoplankton determinations. We also thank 3 unknown referees whose suggestions have helped to clarify some concepts and improve the manuscript.

\section{LITERATURE CITED}

Alberighi L, Franco P, Bastianini M, Socal G (1997) Produttività primaria, abbondanz a fitoplanctonica e campo di irradianza in due stazioni dell'Adriatico Settentrionale. Crociera Marzo e Giugno 1994. Biol Mar Medit 4:17-23

Ban S, Burns C, Castel J, Chaudron Y and 19 others (1997) The paradox of diatom-copepod interactions. Mar Ecol Prog Ser 157:287-293

Ban S, Lee HW, Shinada A, Toda T (2000) In situ egg production and hatching success of the marine copepod Pseudocalanus newmani in Funka Bay and adjacent waters off south-western Hokkaido, Japan: association to diatom bloom. J Plankton Res 22:907-922

Brett MT, Müller-Navarra DC (1997) The role of highly unsaturated fatty acids in aquatic food web processes. Freshw Biol 38:483-499

Buttino I, Miralto A, Ianora A, Romano G, Poulet SA (1999) Water-soluble extracts of the diatom Thalassiosira rotula induce aberrations in embryonic tubulin organisation of the sea urchin Paracentrotus lividus. Mar Biol 134:147-154

Cabrini M, Andri M, Cok S, Pecchiar I, Fonda Umani S (2002) Carbon partitioning among the first trophic levels in the north western Adriatic Basin. Chem Ecol 18:95-105

Calbet A, Saiz E, Alcaraz M (2002) Copepod egg production in the NW Mediterranean: effects of winter environmental conditions. Mar Ecol Prog Ser 237:173-184

Caldwell GS, Olive PJW, Bentley MG (2002) Inhibition of embryonic development and fertilization in broadcast spawning invertebrates by water soluble diatom extracts and the diatom toxin 2-trans, 4-trans decadienal. Aquat Toxicol 60:123-137

Campbell RG, Wagner MM, Teegarden GJ, Boudreau CA, Durbin EG (2001) Growth and development rates of the copepod Calanus finmarchicus reared in the laboratory. Mar Ecol Prog Ser 221:161-183

Ceballos S, Ianora A (in press) Different diatoms induce contrasting effects on the reproductive success of the copepod Temora stylifera. J Exp Mar Biol Ecol

d'Ippolito G, Iadicicco O, Romano G, Fontana A (2002a) Detection of short-chain aldehydes in marine organisms: the diatom Thalassiosira rotula. Tetrahedron Lett 43: $6137-6140$

d'Ippolito G, Romano G, Iadicicco O, Miralto A, Ianora A, Cimino G, Fontana A (2002b) New birth-control aldehydes from the marine diatom Skeletonema costatum. Tetrahedron Lett 43:6133-6136

Fonda Umani S (1996) Pelagic production and biomass in the Adriatic Sea. Sci Mar 60:65-77

Fonda Umani S, Franco P, Ghirardelli E, Malej A (1992) Outline of oceanography and the plankton of the Adriatic Sea. In: Colombo G, Ferrari I, Ceccherelli VV, Rossi R (eds) Marine eutrophication and population dynamics. Proc 25th Eur Mar Biol Symp. Olsen \& Olsen, Fredensborg, p 347-365

Fonda Umani S, Specchi M, Cataletto B, De Olazabal A (1994) Distribuzione stagionale del mesozooplancton nell'Adriatico Settentrionale e centrale. Boll Soc Adriat Sci Trieste 75:145-176

Franco P (1983) L'Adriatico Settentrionale: caratteri oceano- grafici e problemi. In: Atti Congr Assoc Ital Oceanol Limnola 5:1-27

Franco P (1984) Fattori influenti sulla produttività primaria dell'Adriatico Settentrionale. Boll Oceanol Teor Appl 22: $125-140$

Grancini G, Cescon B (1973) Dispersal processes of freshwaters in the Po river coastal area. Limnol Oceanogr 18: 705-710

Guglielmo L, Sidoti O, Granata A, Zagami G (2002) Distribution, biomass and ecology of mesozooplankton in the northern Adriatic Sea. Chem Ecol 18:107-115

Guisande C, Riveiro I, Maneiro I (2000) Comparisons among the amino acid compositon of females, eggs and food to determine the relarive importance of food quantity and food quality to copepod reproduction. Mar Ecol Prog Ser 202:135-142

Gulati RD, Demott WR (1997) The role of food quality for zooplankton: remarks on the state-of-the art, perspective and priorities. Freshw Biol 38:753-769

Hirst AG, McKinnon AD (2001) Does egg production represent adult female growth? A call to account for body weight changes. Mar Ecol Prog Ser 223:179-199

Hure J, Ianora A, Scotto di Carlo B (1980) Spatial and temporal distribution of copepod communities in the Adriatic Sea. J Plankton Res 2:295-316

Ianora A (1998) Copepod life history traits in subtemperate regions. J Mar Syst 15:337-349

Ianora A, Buttino I (1990) Seasonal cycles in population abundances and egg production rates in the planktonic copepods Centropages typicus and Acartia clausi. J Plankton Res 12:473-481

Ianora A, Poulet SA (1993) Egg viability in the copepod Temora stylifera. Limnol Oceanogr 38:1615-1626

Ianora A, Poulet SA, Miralto A (1995) A comparative study of the inhibitory effect of diatoms on the reproductive biology of the copepod Temora stylifera. Mar Biol 121:533-539

Ianora A, Poulet SA, Miralto A, Grottoli R (1996) The diatom Thalassiosira rotula affects reproductive success in the copepod Acartia clausi. Mar Biol 125:279-286

Ianora A, Miralto A, Poulet SA (1999) Are diatoms good or toxic for copepods? Reply to comment by Jónasdóttir et al. Mar Ecol Prog Ser 177:305-308

Ianora A, Poulet SA, Miralto A (2003) The effects of diatoms on copepod reproduction: a review. Phycologia (in press)

Irigoien $\mathrm{X}$, Head RN, Harris RP, Cummings D, Harbour D (2000) Feeding selectivity and egg production of Calanus helgolandicus in the English Channel. Limnol Oceanogr 45:44-54

Irigoien $\mathrm{X}$, Harris RP, Verheye HM, Joly $\mathrm{P}$ and 14 others (2002) Copepod hatching success in marine ecosystems with high diatom concentrations. Nature 419:387-389

Kang HK, Poulet SA (2000) Reproductive success in Calanus helgolandicus as a function of diet and egg cannibalism. Mar Ecol Prog Ser 201:241-250

Laabir M, Poulet SA, Ianora A, Miralto A, Cueff A (1995) Reproductive response of Calanus helgolandicus. II. In situ inhibition of embryonic development. Mar Ecol Prog Ser 129:97-105

Laabir M, Poulet SA, Harris RP, Cueff A, Head RN, Ianora A (1998) Comparative study of the reproduction of Calanus helgolandicus in well-mixed and seasonally stratified coastal waters of the western English Channel. J Plankton Res 20:407-421

Lacoste A, Poulet SA, Cueff A, Kattner G, Ianora A, Laabir M (2001) New evidence of the copepod maternal food effect on reproduction. J Exp Mar Biol Ecol 259:85-107

Miralto A, Barone G, Romano G, Poulet SA and 7 others 
(1999) The insidious effect of diatoms on copepod reproduction. Nature 402:173-176

Miralto A, Ianora A, Buttino I, Romano G, Di Pinto M (2002) Egg production and hatching success in North Adriatic Sea populations of the copepod Acartia clausi. Chem Ecol 18:117-125

Müller-Navarra DC (1995) Evidence that a highly unsaturated fatty acid limits Daphnia growth in nature. Arch Hydrobiol 132:297-307

Nejstgaard JC, Hygum BH, Naustvoll LJ, Båmstedt U (2001) Zooplankton growth, diet and reproductive success compared to simultaneous diatom- and flagellate-microzooplankton-dominated plankton blooms. Mar Ecol Prog Ser 221:77-91

Niehoff B, Madsen SD, Hansen BW, Nielsen TG (2002) Reproductive cycles of three dominant Calanus species in Disko Bay, West Greenland. Mar Biol 140:567-576

Pohnert G (2000) Wound-activated chemical defence in unicellular planktonic algae. Angew Chem Int Ed Engl 39: $4352-4354$

Pohnert G (2002) Phospholipase A2 activity triggers the wound-activated chemical defence in the diatom Thalassiosira rotula. Plant Physiol (Rockv) 129:103-111

Pohnert G, Lumineau O, Cueff A, Adolfph S, Cordevant C, Lang M, Poulet S (2002) Are volatile unsaturated aldehydes from diatoms the main line of chemical defence against copepods? Mar Ecol Prog Ser 245:33-45

Pond D, Harris RP, Head R, Harbour D (1996) Environmental and nutritional factors determining seasonal variability in the fecundity and egg viability of Calanus helgolandicus in coastal waters off Plymouth, UK. Mar Ecol Prog Ser 143: 45-63

Poulet SA, Ianora A, Miralto A, Meijer L (1994) Do diatoms arrest embryonic development in copepods? Mar Ecol Prog Ser 111:79-86

Poulet SA, Ianora A, Laabir M, Klein Breteler WCM (1995a) Towards the measurement of secondary production and recruitment of copepods. ICES J Mar Sci 52:359-368

Poulet SA, Laabir M, Ianora A, Miralto A (1995b) Reproductive response of Calanus helgolandicus. I. Abnormal embryonic and naupliar development. Mar Ecol Prog Ser 129:85-95

Editorial responsibility: Joseph Pawlik (Contributing Editor), Wilmington, North Carolina, USA
Refsgaard HHF, Tsai L, Stadman ER (2000) Modifications of proteins by polyunsaturated fatty acid peroxidation products. Proc Natl Acad Sci USA 97:611-616

Rosahl S (1996) Lipoxygenases in plants - their role in development and stress response. Z Sect C Naturforsch J Biosci 51:123-138

Sameoto DD, Saroszynsky LO, Fraser WB (1980) BIONESSa new design in multiple net zooplankton sampler. J Fish Res Board Can 37:722-724

Smodlaka N (1986) Primary production of the organic matter as an indicator of the eutrophication in the northern Adriatic Sea. Sci Total Environ 56:211-220

Socal G, Pugnetti A, Alberighi L, Acri F (2002) Observations on phytoplankton productivity in relation to hydrography in the Northern Adriatic. Chem Ecol 18:61-73

Starr M, Runge JA, Therriault JC (1999) Effects of diatom diets on the reproduction of the planktonic copepod Calanus finmarchicus. Sarsia 84:379-389

Tosti E, Romano G, Buttino I, Cuomo A, Ianora A, Miralto A (in press) Bioactive aldehydes from diatoms block fertilisation currents in ascidian oocytes. Mol Repr Dev

Turner JT, Ianora A, Miralto A, Laabir M, Esposito F (2001) Decoupling of copepod grazing rates, fecundity and egghatching success on mixed and alternating diatom and dinoflagellate diets. Mar Ecol Prog Ser 220:187-199

Uye SI (1996) Induction of reproductive failure in the planktonic copepod Calanus pacificus by diatoms. Mar Ecol Prog Ser 133:89-97

Vadrucci MR, Basset A, Decembrini F (2002) Quantitative relationships among phytoplankton body size classes and production processes in the North Adriatic frontal region. Chem Ecol 18:53-60

Vollenweider RA, Rinaldi A, Montanari G (1992) Eutrophication, structure and dynamics of a marine coastal system: results of ten-year monitoring along the Emilia-Romagna Coast (northwest Adriatic Sea). In: Vollenweider RA, Marchetti R, Viviani R (eds) Marine coastal eutrophication. Elsevier, Amsterdam, p 63-106

Wendel T, Jüttner F (1996) Lipoxygenase-mediated formation of hydrocarbons and unsaturated aldehydes in freshwater diatoms. Phytochemistry 41:1445-1449

Submitted: October 10, 2002; Accepted: January 16, 2003

Proofs received from author(s): May 15, 2003 